\title{
Distribution of butyltin compounds in the coastal environment of the Bahía Blanca estuary, Argentina
}

Pamela Yanina Quintas ( $\sim$ pquintas@mendoza-conicet.gob.ar)

Universidad Nacional de Cuyo https://orcid.org/0000-0002-2284-8673

Andrés Arias

IADO: Instituto Argentino de Oceanografia

Mónica Álvarez

INQUISUR: Instituto de Quimica del Sur

Claudia Domini

INQUISUR: Instituto de Quimica del Sur

Mariano Garrido

INQUISUR

Jorge Marcovecchio

IADO

\section{Research Article}

Keywords: Butyltins compounds, pollution monitoring, Argentine estuary, multivariate analysis

Posted Date: June 1st, 2021

DOl: https://doi.org/10.21203/rs.3.rs-188410/v1

License: (c) (i) This work is licensed under a Creative Commons Attribution 4.0 International License. Read Full License

Version of Record: A version of this preprint was published at Archives of Environmental Contamination and Toxicology on July 15th, 2021. See the published version at https://doi.org/10.1007/s00244-02100871-x. 


\section{Distribution of butyltin compounds in the coastal environment of the Bahía Blanca estuary, Argentina}

Pamela Y. Quintas ${ }^{a, 1,{ }^{*}}$, Andrés H. Arias ${ }^{a, b}$, Mónica B. Alvarez ${ }^{b, c}$, Claudia E. Dominiib, Mariano Garrido ${ }^{\mathrm{b}, \mathrm{c}, *}$, Jorge E. Marcovecchio ${ }^{\mathrm{a}}$

a Instituto Argentino de Oceanografía (IADO), Universidad Nacional del Sur (UNS)CONICET, Bahía Blanca, Argentina.

b Departamento de Química, Universidad Nacional del Sur (UNS), Bahía Blanca, Argentina.

c INQUISUR, Departamento de Química, Universidad Nacional del Sur (UNS)CONICET, Av. Alem 1253, 8000 Bahía Blanca, Argentina.

${ }^{*}$ Corresponding author. Tel: +54-261-5259738 (P.Y. Quintas)

E-mail address: pquintas@mendoza-conicet.gob.ar; ORCID: 0000-0002-2284-8673

${ }^{*}$ Corresponding author. Tel: +54-291-5595100 (M. Garrido)

E-mail address: mgarrido@uns.edu.ar; ORCID: 0000-0002-2284-8673

Other authors: Andrés H. Arias (andresarias.ar@gmail.com, ORCID: 0000-0003-3322-

330X); Mónica B. Alvarez (malvarez@criba.edu.ar, ORCID: 0000-0002-9474-6393);

Claudia E. Domini (dominiclaudia@hotmail.com, ORCID: 0000-0003-0483-0805) and Jorge E. Marcovecchio (jmjorgemar@gmail.com, ORCID: 0000-0002-0384-4562)

\footnotetext{
${ }^{1}$ Present address: Laboratorio de Química Analítica para Investigación y Desarrollo (QUIANID), Instituto Interdisciplinario de Ciencias Básicas, Universidad Nacional de Cuyo, Mendoza, Argentina.
} 


\section{Abstract}

This study evaluates for the first time the distribution and accumulation of butyltin compounds (BTs) in different compartments as seawater, sediments, suspended particulate matter (SPM) and mussels (Brachidontes rodriguezii) in the Bahía Blanca estuary. The samples were collected from six sampling sites with different anthropogenic impact. A better visualization and interpretation of data were achieved using chemometric tools (Tucker4 model), which made it possible to reveal the main relationships between the variables. This analysis showed the presence of BTs in all environmental compartments along the estuary, even in sites with low human intervention. The relationships found between BTs levels, seasons and environmental matrices show the importance of biological processes such as phytoplankton blooms and remobilization of sediments (by tidal dynamics and/or periodic dredging) in the BTs distribution and degradation. In addition, partition coefficients showed that mussels mainly bioaccumulate tributyltin through sediment, water and, to a lesser extent, from SPM.

Keywords: Butyltins compounds; pollution monitoring; Argentine estuary; multivariate analysis 


\section{Introduction}

Organotin compounds (OTCs) were used in a wide range of applications (Chen et al. 2017). However, in the mid-70s, the OTCs began to increase their notoriety due to the outstanding biocidal properties of triorganotin derivatives. Particularly, tributyltin (TBT) has been used as an active component in antifouling paint formulations to prevent biofilms formation on marine structures and ship hulls (van Gessellen et al. 2018).

The TBT reaches the marine environment by leaching itself from these paints (Okoro et al. 2016). Once in the environment, TBT and its degradation products (dibutyltin (DBT), monobutyltin (MBT) and, finally, inorganic tin) can be involved in different processes, such as diffusion, sorption, lixiviation, sedimentation, biodegradation and resuspension (dos Santos et al. 2016). Degradation of TBT may occur by photolysis, chemical and thermal cleavage, or through the microorganisms' activity (El Hadj et al. 2016). In turn, the butyltins (BTs) bioavailability is influenced by numerous environmental factors, physicochemical variables, seasonal variations and geographic conditions (Fang et al. 2012). Moreover, BTs can be found in sediments, in dissolved and particulate forms, in both pore and column water and can even be readily incorporated into the tissues of filter-feeding zooplankton, grazing invertebrates and, eventually, into higher organisms such as fishes, water birds, and mammals (Ohji et al. 2007).

Owing to the ecotoxicological effects of TBT (Filipkowska and Lubecki, 2016; Martínez et al. 2017), the International Maritime Organization (IMO, 2001) adopted the International Convention on the Control of Harmful Antifouling Systems (AFS Convention), which banned the use of TBT as active component in antifouling systems for ships around the world and it has come into force since 17 September 2008. However, until now the restriction has not been implemented for DBT and MBT (Fang et al. 2017). In spite of this regulation, in few years a large number of studies have reported that TBT is still present in the environment (Abraham et al. 2017, Batista et al. 2016, Deng et al. 2018, Maciel et al. 2018). This is particularly important in estuaries with restricted circulation, which host harbors, marinas and shipyards (Castro and Fillmann, 2012). This 
is the case of the Bahía Blanca estuary (BBE), an area under increasing anthropogenic pressure, which is the second largest estuary in Argentina and includes one of the most important industrial hubs in South America.

Considering the possible incidence of BTs in the whole ecosystem, it is important to monitor these compounds in different environmental matrices, in order to assess their distribution and bioavailability (dos Santos et al. 2016). In this way, the aim of this study was to analyze the levels of TBT, DBT and MBT in several samples from different environmental compartments (sediment, suspended particulate matter, water column and mussel tissues), which were seasonally collected (temporal dimension) for several sampling points (spatial dimension) in the BBE. The visualization and interpretation of data were carried out by chemometric multivariate analysis, particularly using the Tucker4 model (Bro, 1998; Marinho et al. 2019). The current study is the first comprehensive analysis performed for BTs in different environmental matrices by the assistance of $\mathrm{N}$-way chemometric tools.

\section{Materials and methods}

\section{Study area}

BBE is located in the South-West of Buenos Aires Province, Argentina (38 $45^{\prime}-39^{\circ} 40^{\prime} \mathrm{S}$ and $61^{\circ} 45^{\prime}-62^{\circ} 20^{\prime} \mathrm{W}$ ) (Fig. 1). The estuarine area comprises a dense arrangement of meandering channels and islands, surrounded by extensive intertidal mudflats and marshes (Dutto et al. 2017). Approximately $85 \%$ (250.000 ha) of the total area of this system is under legal protection through four ecological reserves (Bravo et al. 2018). In spite of this, the BBE undergoes a strong anthropogenic pressure related to urban and industrial activities on its northern boundary and also houses the most important deepwater port system in Argentina. Especially, deepening dredging activities carried out on the Main Navigation Channel promote resuspension, transport and redistribution of sediments (Grecco et al. 2011). 
Six sites, affected by different intensities of human activities, were selected from the outer to the inner zone of the estuary (Fig. 1). Sampling station S1 is located in Rosales Harbor, a coastal town at the middle zone of the Main Navigation Channel. This place is frequented by oil tankers and port service vessels and is in the proximity of the Belgrano Harbor, the most important military harbor of Argentina, where the hulls of many commercial and military ships are continuously repaired and painted. S2 is located in Ingeniero White Harbor, near a thermoelectric generation plant facility. This site is one of the major commercial and general cargo ports of Argentina in which fishing and also recreational activities normally take place. The S3 site, which is also located in Ingeniero White Harbor, is characterized by the presence of numerous fishing boats. S4 lies near the Galvan Harbor, in the vicinity of a petroleum derivatives loading buoy. Cuatreros Harbor (S5) is located in the inner part of the estuary, in a small recreational/fishing port. Finally, the S6 sampling point (Villarino Viejo) is in the head of the estuary; an area of rural lands with relatively low anthropogenic impact.

\section{Samples}

Sampling was performed during 2014 on board of the IADO IV research vessel, at low tide and every three months. Sediment samples were collected from the superficial layer (1-5 cm) using a stainless-steel grab sampler and an acrylic corer. Native mussels (Brachidontes rodriguezii) were collected according to their availability, from natural banks, dock columns, platforms, surface sediments, or in surface water (0-1 m). Sixty mussels from each sampling point were used (on average) to prepare composite samples. Furthermore, approximately $4 \mathrm{~L}$ of seawater were collected in amber glass bottles at each sampling location. Immediately thereafter, the samples were refrigerated in iceboxes, stored on containers avoiding exposure to light and then rapidly transported to the laboratory. Afterwards, the water samples were filtered through a polycarbonate membrane with a pore size of $0.4 \mu \mathrm{m}$ (Millipore ${ }^{\circledR}$ HTTP 04700 ) using a vacuum pump to avoid that BTs absorbed onto SPM interfere in the analytical determination of these 
pollutants in the water samples (Berg et al. 2001; Michel et al. 2001). Thus, both the filtered estuarine water samples and the suspended particulate matter (SPM), which is retained in the filter, were obtained. Before using, membranes were treated with $0.7 \%$ nitric acid, rinsed with deionized water, and dried at $50{ }^{\circ} \mathrm{C}$ to a constant weight. The filters with the retained material, the sediments and the mussels samples were frozen ($\left.18^{\circ} \mathrm{C}\right)$, lyophilized, and stored at $4^{\circ} \mathrm{C}$ until analysis. The water samples were stored in the dark in amber glass bottles at $4^{\circ} \mathrm{C}$ until further use.

\section{BTs determination}

At the beginning of the procedure tripropyltin chloride (TPrT) is added as surrogate recovery standard together with the sample and ultrapure deionized water in a centrifuge tube. Then, BTs determination in seawater samples was performed by a liquid-liquid extraction and derivatization with sodium borohydride in hexane (Quintas et al. 2019). For sediments, SPM and mussels, the freeze-dried samples were put in contact with a methanolic solution of sodium hydroxide under ultrasound energy (Quintas et al. 2018). Then, the same derivatization reaction was carried out by adding sodium borohydride in hexane. In all cases, one microliter of the hexane layer was injected on split-less mode $\left(220^{\circ} \mathrm{C}\right.$ ) in a gas chromatograph (Agilent $7890 \mathrm{~B}$ ) coupled to a mass detector (Agilent 5977A). Before injection in the gas chromatograph, tetrabutyltin chloride (TeBT) standard solution (internal standard) was added.

The GC column was an HP-5MS fused silica column (30 m; 0.25 mm i.d.; $0.25 \mu \mathrm{m}$ film thickness) with helium as carrier gas (flow rate of $1 \mathrm{~mL} \mathrm{~min}{ }^{-1}$ ). The mass spectrometer was operated in the electron impact mode $(70 \mathrm{eV})$. The temperature program was $55^{\circ} \mathrm{C}$ for $1 \mathrm{~min}$, then $20^{\circ} \mathrm{C} \mathrm{min}-1$ up to $200^{\circ} \mathrm{C}$, maintaining that temperature for $5 \mathrm{~min}$. The organotin hydrides were determined in the selected ion monitoring (SIM) mode. The selected ions were 119, 121, 177, 179, 233 and $235 \mathrm{~m} / \mathrm{z}$ for TBT; 121, 177 and $179 \mathrm{~m} / \mathrm{z}$ for DBT and the same ions selected for DBT plus the ion $119 \mathrm{~m} / \mathrm{z}$ for MBT. For TeBT the ions were the same as for TBT plus 289 and $291 \mathrm{~m} / \mathrm{z}$. The TPrT was detected using the 
ions 119, 121, 163, 165, 205 and $207 \mathrm{~m} / \mathrm{z}$. Each of the BTs was confirmed by the retention time and the abundance ions against certified BTs standards. As examples, chromatograms of the standard solution with MBT, DBT, TBT, TrPT and TeBT, and from the extract of the mussel and water samples are illustrated in Fig S3.

\section{Quality control}

The validation of the procedure was evaluated in terms of trueness and precision, using the PACS-2 reference material for sediments. The other samples (i.e. water, SPM and mussels) were spiked at three concentration levels for each of the BTs and then analyzed by six times. The recoveries, used for assessing the trueness, ranged between 82 and $97 \%$ for the reference material and between 94 and $100 \%$ for the other samples. Precision was evaluated under repeatability conditions and estimated as RSD (\%) values. They varied between 1.1 and $1.9 \%$ for the determinations of PACS-2 reference material and between 0.9 and $7.1 \%$ for the spiked samples. The results were in good agreement with the sediment certified values (no statistical differences were obtained, $\alpha=0.05)$ and were also in accordance with the EURACHEM analytical validation recommendations, i.e., recovery of $70-120 \%$ and RSD (\%) below 20\% (EURACHEM 1998; Thompson et al. 2002). Limits of detection (LODs) were calculated considering a $\mathrm{S} / \mathrm{N}=3$ (signal to noise ratio) and taking the baseline of the chromatograms as an estimation of noise (Vidal et al. 2003). For sediments and SPM samples the LODs obtained were $0.8,1.1$ and $3.5 \mathrm{ng} \mathrm{Sn}^{-1}$ dry wt. for TBT, DBT and MBT, respectively. LODs for mussels samples were: TBT: 1.2; DBT: 1.8 and MBT 3.0 (ng Sn $\mathrm{g}^{-1}$ dry wt.). Finally, LODs for water samples were $2.1,5.4$, and $8.4 \mathrm{ng} \mathrm{Sn} \mathrm{L}^{-1}$ for TBT, DBT, and MBT, respectively.

To assess the extraction efficiency, TeBT was used as surrogate standard and it was added to the samples at known concentrations and they were then subjected to the analytical procedure using, in this case, TPrT as internal standard. Thus, only the 
extraction step is evaluated because the TeBT does not undergo the derivatization process. The recoveries obtained were of $100 \%$.

\section{TBT degradation}

As mentioned above, TBT may undergo degradation via successive debutylation (Hoch, 2001). This degradation can be evaluated through the butyltin degradation index (BDI) (Díez et al. 2002), which is calculated as the ratio between the concentration of TBT and the sum of their breakdown products, i.e. DBT and MBT:

$$
B D I=\frac{T B T}{D B T+M B T}
$$

A BDI > 1 would indicate recent inputs of TBT; on the contrary, BDI values less than 1 would imply that the parent compounds have been degraded and therefore the contamination should be considered 'old'. However, many factors could be responsible for the degradation of these compounds in the marine environment (Diez et al. 2005; Sousa et al. 2009) and it is not easy to assess how recent the input is.

Nevertheless, in view of the fact that the samples were collected at the same time, in a relatively small area and under similar environmental conditions, using the BDI seems to be adequate. The use of BDI is based on the assumption that the decomposition of TBT is the only source of DBT and MBT (Díez et al. 2002). Data related to BDI is shown as Supplementary Table S1.

\section{Additional analysis and measurements}

Temperature, $\mathrm{pH}$, turbidity and conductivity were measured at each sampling point. Salinity was estimated by conductivity and expressed as practical salinity units. The measurements were made in situ using a Horiba U-10 multisensor probe and given as Supplementary Material (Table S2). 
The sediment granulometry was analyzed by laser diffractometry (Malvern Mastersizer 2000) and the results were expressed as the percentage of sediment particles below 63 $\mu \mathrm{m}$ in diameter (Supplementary Table S3).

Organic matter, expressed as percentage (\%OM), was determined by ignition loss. $\mathrm{A}$ subsample of $10-20 \mathrm{~g}$ of dry sediment $\left(105^{\circ} \mathrm{C}\right.$ until constant weight) was heated in a muffle furnace at $500^{\circ} \mathrm{C}$ for $3 \mathrm{~h}$ (Commendatore and Esteves, 2004). Particulate Organic Matter (POM) concentration was determined following the Strickland and Parsons method (1968) (range 10-4000 $\mathrm{mgC} \mathrm{m}^{-3}$ ) using a Jenway 6715 UV-vis spectrophotometer. Before performing the analysis, $\sim 250 \mathrm{~mL}$ of seawater were filtered through a muffled $\left(450-500{ }^{\circ} \mathrm{C}, 1 \mathrm{~h}\right)$ glass fibre membrane $(47 \mathrm{~mm}$ in diameter and 0.7 $\mu \mathrm{m}$ pore size) and frozen at $-20^{\circ} \mathrm{C}$ in plastic bottles (Grasshoff, 1976; APHA, 1998). Both parameters are shown in Supplementary Table S4.

In addition, in order to evaluate the physiological status of mussels, the condition index (CI) was determined (Lau and Leung, 2004) according to the following equation (Orban et al. 2002):

$$
\text { CI \% }=\frac{\text { dry tissue weight }(g)}{\text { dry shell weight }(g)} \times 100
$$

This index could exhibit natural fluctuations as a result of the food availability, spawning, reproduction and the degree of stress of the organism, etc. The increase in the $\mathrm{Cl}$ represents greater amounts of organic constituents in the individuals, which are associated with growth. On the contrary, a decrease in the $\mathrm{Cl}$ reflects periods of stress and implies a greater use of the reserves of the organism. Condition index for the current study could be found in Fig. S1.

\section{Data treatment}

The experimental data were arranged in a four-way array $\underline{\mathbf{x}}(I \times J \times K \times L)$. The values for some variables were beneath the detection limits and they were therefore substituted 
by a value equal to a half of the limit of detection for the corresponding variable (Álvarez et al. 2008).

In this arrangement, the $I$-mode is related to the number of studied samples, $\mathrm{J}$-mode corresponds to the BTs, the $K$-mode is related to the seasons of the year and $L$-mode to the different environmental compartments analyzed, i.e. sediments, mussels, SPM and water. All data were scaled within the $J$-mode to allow the BTs having the same possibility to contribute to the model (Singh et al. 2007). The data array $\underline{\mathbf{X}}$ was decomposed applying a Tucker4 model (Bro, 1998) using the N-way Toolbox (Bro, 2013) in Matlab 8.0 (The MathWorks). Four loading matrices were obtained in accordance with the following equation:

$$
\underline{X}=\sum_{p=1}^{P} \sum_{q=1}^{Q} \sum_{r=1}^{R} \sum_{s=1}^{S} a_{i p} b_{j q} c_{k r} d_{l s} g_{p q r s}+e_{i j k l}
$$

where $\mathrm{P}, \mathrm{Q}, \mathrm{R}$ and $\mathrm{S}$ are the number of factors in each mode, $\mathrm{e}_{\mathrm{ijkl}}$ are the elements of the residual array $\underline{\mathbf{E}}$ and the $\mathrm{g}_{\mathrm{pqrs}}$ are the elements of the core array $\underline{\mathbf{G}}(\mathrm{P} \times \mathrm{Q} \times \mathrm{R} \times \mathrm{S})$. This core array gives information about the interactions among the loading vectors in the different modes (Bro, 1998). The optimal model was chosen on the basis of the residual sum of squares and the degrees of freedom (named st-criterion) and using the so-called 'convex hull' method (Ceulemans and Kiers, 2006; Stanimirova et al. 2009). The model in the 'convex hull' with the largest st-coefficient was selected.

The data were also analyzed using INFOSTAT software version 2008. The normal distribution was evaluated with the Shapiro-Wilk test $(p>0.05)$. Kruskal-Wallis test was used for the comparison among data from different sites and seasons. Correlations between BTs levels and the physicochemical variables were evaluated using Spearman's test ( $p<0.05$ was regarded as significant).

\section{Results and discussion}

\section{Butyltin levels and physicochemical variables}


BTs concentrations are shown in Table 1. No statistically significant differences were found between the sampling sites (Kruskal Wallis, $p>>0.05$ ) in all the compartments, indicating a quite homogeneous distribution along the study area. This fact could reflect a widespread diffusion due to the strong vertical mixing and tidal currents which traditionally led to define the estuary as vertically homogeneous (Freije et al. 2008). Data collected for BTs concentrations could be described, in a general way, as follows:

Sediments: TBT was quantified in 15 of the 24 sediment samples. Levels ranged from

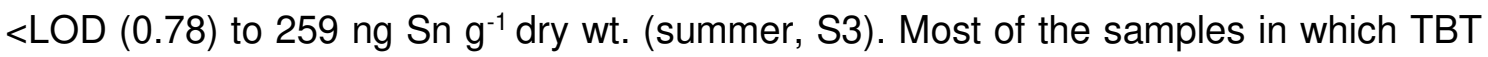
was not quantified belong to the sampling of winter and spring. DBT was quantified in 21

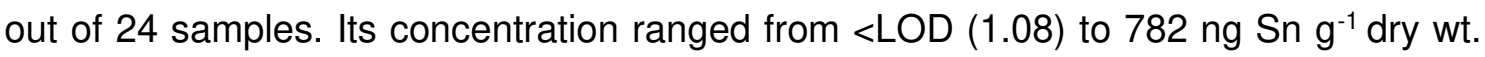
(spring, S5). The lowest levels of DBT were found in winter (according to Kruskal-Wallis test, winter significantly differed from the other seasons $(p=0.01))$ and the highest values were observed in spring. MBT was quantified in 23 of the total samples and its concentration ranged from < LOD (3.5) to $831 \mathrm{ng} \mathrm{Sn} \mathrm{g}^{-1}$ dry wt. (autumn, S3). No statistically significant differences were found between the seasons (Kruskal Wallis, $p>>0.05)$.

Regarding the grain size of the sediments, all the sampling stations were classified as silty/clay. In general, the silt/clay ratios varied within 0.77 and 1.60, growing from site $\mathrm{S1}$ to the innermost part of the estuary. Even though the BTs would be preferably adsorbed in the fine fraction (Hoch et al. 2003), no significant correlation was found between the BTs concentrations and the grain size ( $p>0.05)$. This lack of correlation can be attributed to the high variability in the sediment deposition dynamics caused by the high transport rates of sediments in the study area (Perillo and Piccolo, 1991) and the remobilization of the sediments that occurs as a consequence of the periodic dredging on the Main Navigation Channel.

Finally, the concentration of \%OM varied from $2.1 \%$ (S6, autumn) to $7.9 \%$ (S5, winter) (Table S4). Despite the fact that organic matter has been reported as the main adsorbing 
component of BTs (Berg et al. 2001), no correlation was found between OM\% and BTs concentrations $(p>0.05)$ at the different sites or with respect to the seasons.

SPM: TBT and DBT were quantified in all the samples of SPM. TBT levels ranged from

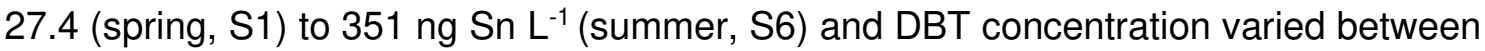
30.3 (spring, S1) to $461 \mathrm{ng} \mathrm{Sn} \mathrm{L}^{-1}$ (summer, S6). On the other hand, MBT levels ranged from < LOD to $790 \mathrm{ng} \mathrm{Sn} \mathrm{L}^{-1}$ (autumn, S1) and was under the LOD in all the samples collected in spring. POM was also studied and the values were between $490 \mathrm{mg} \mathrm{C} \mathrm{m}^{-3}$ (S6, spring) and $1728 \mathrm{mg} \mathrm{C} \mathrm{m}^{-3}$ (S1, summer) (Table S4). Given the affinity of the MBT for organic matter (Hongxia et al. 1996), it makes sense to find low concentrations of this compound in the SPM in spring. Despite this fact, even though the content of organic matter plays an important role in the destination, mobility and availability of the BTs in marine-coastal ecosystems; no significant correlations ( $p>0.05)$ were found among BTs concentrations and POM.

Water column: TBT was quantified in all samples and its concentrations ranged from 21.4 (summer, S6) to $387 \mathrm{ng} \mathrm{Sn} \mathrm{L^{-1 }}$ (autumn, S6). On the other hand, DBT only was

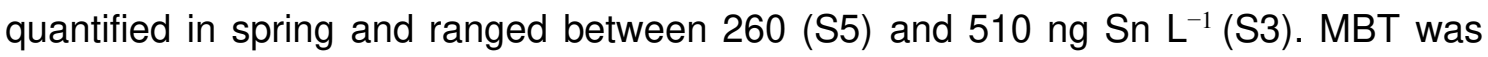
found between 289 (summer, S6) and 647ng Sn L-1 (autumn, S2). We have recorded BTs in water samples within the Bahía Blanca estuary for the first time. As there are no previously published data from the study area, the concentrations from the present study were compared to data from other parts of the world. Okoro et al. 2016 reported TBT levels between 67 and $111290 \mathrm{ng} \mathrm{Sn} \mathrm{L^{-1 }}$ in Cape Town harbor in South Africa and TBT concentrations from 140 to $1900 \mathrm{ng} \mathrm{Sn} \mathrm{L^{-1 }}$ were founded by Al-shatri et al. 2015 in Saudi Arabia. In both research, their maximum TBT levels described were much higher than that reported in this study. At the same time, the concentrations found in BBE were considerably higher than those reported in Korean coasts with maximum TBT levels of 
23.9 and $10.2 \mathrm{ng} \mathrm{Sn} \mathrm{L}^{-1}$ (Kim et al. 2014 and Lam et al. 2017) and the reported one by Liu et al. 2011 in Taiwan (28.8 ng Sn L-1).

The mean values of the physicochemical variables measured in situ in the column water are summarized in Table S2. All the parameters are within the previously reported ranges in the study area (Spetter et al. 2015). According to the Kruskal Wallis test, no significant differences were found between the sites ( $p>>0.05$ ), that would indicate that the evaluated variables were homogeneous with independence of the site, probably as a result of the mixing force of the tidal currents. No correlation was found $(p>0.05)$ between the different physicochemical parameters evaluated in the water column (that is, particulate organic matter, temperature, turbidity, $\mathrm{pH}$ and salinity) with the levels of TBT, DBT and MBT found in said compartment. Possibly, the presence of micro-organisms, dredging activities and characteristic tidal currents, among other factors, could hide a clear correlation among the physicochemical variables and the BTs levels (Basheeru et al. 2020; Simonetti et al. 2017).

Mussels (Brachidontes rodriguezzi): Brachidontes rodriguezii is a bivalve mollusk belonging to the family of Mytilidae (d'Orbigny, 1842). It is the dominant organism on middle and lower intertidal rocky substrate in warm-temperate shores of Argentina and acts as key species in the ecosystem (Adami et al. 2008). This specie of mussel can be use as bioindicator to monitor the pollutants due to its wide geographical distribution, sessile lifestyle, easy sampling, tolerance to a considerable range of salinity, resistance to stress and high accumulation of a wide range of chemicals (Baumard et al. 1998; Farrington and Tripp, 1995). Furthermore, typically mussels are not able to depurate pollutants, because they have not got an efficient system to metabolize them (Burgeot et al. 2001). This underlines the fact that we can use them as a good bioindicator. They also bioaccumulate pollutants throughout their life and analysis of their tissue will give us an indication of the bioavailable fraction of TBs environmental contamination. 
TBT and DBT were quantified in 18 out of 24 samples. The lowest TBT and DBT levels were found in autumn and spring (Table 1). The TBT levels varied between < LOD $(0.8)$

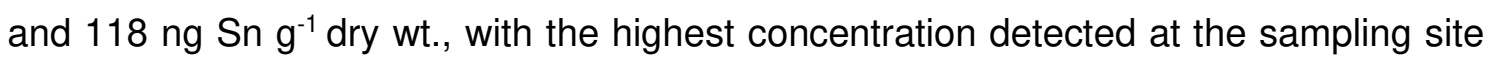
S5 in summer. DBT levels ranged from <LOD to $100 \mathrm{ng} \mathrm{Sn} \mathrm{g}^{-1}$ dry wt. (winter, S2). MBT values ranged from < LOD to $51.35 \mathrm{ng} \mathrm{Sn} \mathrm{g}^{-1}$ dry wt. (summer, S4). No seasonal differences were observed in BTs levels for the native mussels.

Regarding the condition index $(\mathrm{Cl})$, it varied between 3.8 and 10.7 (Supplementary Fig. S1). No significant differences were found between the different sampling sites (Kruskal Wallis, $p>0.05$ ), suggesting that the location in the estuary did not affect the mussels' characteristics. Moreover, $\mathrm{Cl}$ began to increase in winter reaching its maximum in spring. However, no correlation between $\mathrm{Cl}$ and BTs concentrations was found. Rather, this behavior could be related to the availability of food during the so-called "phytoplankton bloom" (Guinder et al. 2015) which seems to be a key factor that regulates the $\mathrm{Cl}$ (Arrieche et al. 2002).

\section{Multivariate analysis}

\section{The loading plots}

Sometimes, inspection of the data tables is not enough to discover the linkages between the different variables. Chemometric tools can help to interpret and clarify these hidden relationships. The experimental data inherently has a four-way structure, i.e. three BTs were analyzed in several compartments of different nature for various sampling sites, in the four seasons. Thus, Tucker4 was the selected multi-way method to extract useful information from the data set because of its capability to deal with different numbers of factors in each mode (i.e. site of samples, BTs, seasons and environmental compartments).

In Supplementary Fig. S2 shows the deviance plot with the different model complexity $(P \times Q \times R \times S)$. Nine models were located in the lower boundary (the so-called convex hull). The Ceulemans-Kiers st-coefficients were then calculated for these nine models, 
as shown in the Table in Fig. S2. The explanation about their calculation can be found elsewhere (Stanimirova et al. 2009). The convex hull method makes it possible to identify suitable models in terms of low deviance and high number of degrees of freedom. However, several models lie on the line defined by the convex hull (some of them have a low deviance and a low number of degrees of freedom, others have a high deviance and number of degrees of freedom) as can be seen in Fig. S2. To select the optimal model among the candidates selected by the convex hull, we use the st criterion (Ceulemans and Kiers, 2006; Stanimirova et al. 2009). The model with the highest st coefficient was selected as the optimal. Therefore, the model with a complexity $(2 \times 2 \times$ $4 \times 4$ ) was chosen for the interpretation of the distribution of BTs in BBE (see the table in the inset of Fig. S2). It is important to note that the low explained variance values $\left(\mathrm{SS}_{\mathrm{Fit}} / \mathrm{SS}_{\mathrm{total}}\right)$ obtained for the selected model are not uncommon when dealing with environmental data, which are affected by high noise due to the weather conditions and to the relatively high experimental error in some variables (Leardi et al. 2000).

Fig. $2 a$ shows the loading plot for the I-mode (sampling sites). All sampling sites show similar negative values for Factor 1 but present a greater variability for Factor 2 . In this way, site S3 appears separately with respect to the other sampling points. One possible explanation for this fact is that the BTs concentrations in this site were, in general, the highest recorded for most of the seasons in the diverse environmental compartments. Indeed, S3 is characterized by the presence of numerous fishing and recreation boats throughout the year, which could lead to high concentrations of TBT. On the other hand, the extreme sampling sites in the estuary (S1 and S6) appear together while the other sites are grouped in the second quadrant of the Factor 1 vs. Factor 2 plot. This behavior could indicate that these sampling sites have similar characteristics regarding the BTs concentration although they are located in the extreme points of the estuary. In addition, the sites S4 and S5 appear close to each other and this would indicate similar overall BTs concentrations. Again, the tidal currents seem to have an important role in the transport of pollutants through the BBE. 
In the butyltins mode (J-mode), all the BTs have negative values for Factor 1 (Fig. $2 b$ ). The higher the number of butyl substituents in the molecule, the higher and negative the Factor 1 is. Regarding Factor 2, TBT and MBT show negative values whereas DBT has a positive one, which could be related to the different affinity of the BTs for the organic matter (Hongxia et al. 1996). In fact, the order according to Factor 2 is in agreement with the order of desorption reported by Dowson et al. (1996), i.e DBT>TBT>MBT.

The $K$-mode (seasons) involves four factors. When Factors 1, 2 and 3 are plotted, each season appears in a different quadrant, which reflects the contrasts in the behavior of the BTs in the different times of the year (Fig $2 c$ shows, as an example, the plot of F2 vs. F1). On the contrary, all the seasons have negative values for Factor 4 (Fig. $2 d$ only shows F4 vs. F3 for simplicity).

The $L$-mode also involves four factors and contains information about the environmental compartments (Figs. $2 e$ and $2 f$ show some combinations of factors to give only substantial information and not to be repetitive). In the graphs obtained for the compartment mode, the different types of samples are grouped in a particular way. When Factor 1 is involved in the graph, the mussels appear to be separated from the other compartments. On the other hand, Factor 2 discriminates the water column from the other types of samples. Factor 3 groups water, mussels and SPMs together, leaving sediment aside. Factor 4 separates sediment and SPMs from water and mussels.

\section{The core elements}

The interpretation of the distribution of the different variables in each mode is not always easy and the relationship among these variables could be revealed by studying the elements of the core matrix. The core array obtained after Tucker4 decomposition (Eq.1) contains information about the relationships among the different elements of the loading vectors in each mode. A better explanation of the system could be achieved by an inspection of these relationships. The core elements arise from the product of the loading values, in both magnitude and sign (i.e. aip $\times$ bjq $\times c k r \times d l s$ ). In this sense, there are a 
lot of combinations of loading values taking into account that there are two factors for the first and second modes and four factors for the third and fourth modes. The more important core values were those that collected a high percentage of the variability observed in the core matrix (Stanimirova et al. 2009). Thus, Table 2 reports the four core values having the higher contributions.

The first core element

The first core element $[1,2,1,1]$ has a value of -6.76 . It accounts for the relationships between the first factors in the modes $\mathrm{I}, \mathrm{K}$ and $\mathrm{L}$ and the second factor in the $\mathrm{J}$-mode. Since the core value is negative, the loadings of each mode must be combined in such a way that the product among them gives a negative result. The loadings for Factor 1 in the I-mode are always negative (Fig. 2 a), whereas the Factor 2 in the J-mode, and the Factor 1 in both $\mathrm{K}$ - and L-modes had both positive and negative values. Therefore, four possible combinations are possible to give a negative core value:

A. (-) Factor 1, I-mode $\times(-)$ Factor 2, J-mode $\times(+)$ Factor 1, K-mode $\times(-)$ Factor 1, Lmode

B. (-) Factor 1, I-mode $\times(+)$ Factor 2, J-mode $\times(+)$ Factor 1, K-mode $\times(+)$ Factor 1, Lmode

C. (-) Factor 1, I-mode $\times(+)$ Factor 2, J-mode $\times(-)$ Factor 1, K-mode $\times(-)$ Factor 1, Lmode

D. (-) Factor 1, I-mode $\times(-)$ Factor 2, J-mode $\times(-)$ Factor 1, K-mode $\times(+)$ Factor 1, Lmode

We will explain the four possible relationships observed for the first core value:

Combination $1 \mathrm{~A}$

As mentioned above, the loadings for Factor 1 in the I-mode are always negative and all sampling points contribute to this Factor in a similar way. So, no particular appreciation 
could be made about the sampling sites, which is in accordance with the Kruskal-Wallis test, for which no statistical differences were found among the sampling sites, as mentioned in section 3.1 .

The negative loadings for Factor 2 in the J-Mode correspond to the MBT and TBT (Fig. $2 \mathrm{~b}$ ), the positive loadings in the K-mode are related to autumn (spring in a lesser extent) and the negative loadings for the L-mode are linked to sediment and water samples (SPM in a lesser extent). These relationships could be explained as follows: In a global manner, the amounts of TBT and MBT were higher in autumn for both sediment and water samples. In this season there is a notable increase in the maritime traffic due to the cereal export activities of the Bahia Blanca Port (from April to June), which may explain the increase in TBT levels. Furthermore, a recent study showed that recreational boats continue to be sources of BTs into the environment due to their presence in historic paint layers on leisure vessels (Lagerström et al. 2017). The authors indicated that the old TBT-based coatings were not properly removed from the vessels, but only covered with a new coat of non-TBT paint. Therefore, this could be one of the causes of the BTs presence in the BBE, in addition to the industrial wastes and sediment removal that occur in the sampling area. As mentioned above, the tidal currents that characterize the study area affect the transport and recirculation of pollutants and could contribute with the dispersion of TBT throughout the estuary. Probably for these reasons the BDI value (Table S1) calculated in autumn for the more internal sampling point (S6), which has a relatively low anthropogenic impact, exceeded the unit in both sediment and water samples.

\section{Combination 1B}

Another possible relationship established by the first core element links the concentration of DBT (positive contribution to Factor 2 in the $J$-mode) to the autumn (more positive contribution to Factor 1 in the $K$-mode) and the mussel samples (the only positive for 
Factor 1 in the $L$-mode). This could be due to the fact that the only season in which DBT was not detected in any sample of Brachidontes rodriguezii was autumn.

The levels below the LOD (for both TBT and DBT, see Table 1) could be related to the BTs elimination rate constant in the mussels, which could be accelerated when the environment reaches high concentrations of these pollutants (Furdek et al. 2012; Tang et al. 2010). Some authors have found in other bivalve species that the steady state was achieved earlier and the elimination rate was higher when mollusks were subjected to larger amounts of TBT (Gomez-Ariza et al. 1999). Perhaps, this unusual behavior - TBT level in mussels are low while those in the water column are high - could be explained by the accumulation potential of this particular mollusk species.

\section{Combination $1 \mathrm{C}$}

Also, the concentration of DBT (positive contribution to Factor 2 in the J-mode, as already commented) is related to the spring season (the most negative contributing to Factor 1 in $\mathrm{K}$-mode) and with the water and sediment samples (similar and negative contribution to Factor 1 in the L-mode). This could be related with the high DBT concentrations generally found in the seawater and sediment samples in spring, which was generally higher than those determined for this compound in the other seasons. Actually, as stated in section 3.1, in seawater the DBT was determined only in the spring season. In addition, sediment samples collected at sites S2, S3, S4 and S5, in spring, show a high concentration of DBT (Table 1).

Much evidence suggests that biotic degradation is one of the major pathways for the removal of TBT from the environment (Gadd, 2000), turning it sequentially to DBT and MBT (Bernat and Długoński, 2006). The increase of DBT concentrations in both sediments and column water in spring could be related to a degradation process caused by diatoms (Fang et al. 2017). In fact, the internal zone of the BBE is characterized by a flowering of diatoms during the winter-spring (June-September) (Guinder et al. 2015) known as "phytoplankton bloom". Also, high DBT concentrations in spring in the water 
column could be due to lower amounts of DBT adsorbed onto the SPM (in other seasons DBT in SPM is much higher).

Furthermore, Dowson et al. (1996) have reported that the DBT in sediments, once formed from TBT degradation, could undergo two different processes: on the one hand, it could be degraded to MBT and, on the other hand, it could be desorbed into the surrounding water column. The high rate of biological degradation in spring possibly generates a high amount of DBT and part of it is redissolved in the water column (Selegman et al. 1986, 1996). In the same vein, Hongxia et al. (1996) have reported that DBT shows the lower affinity for the organic matter, so tends to remain in the column water.

\section{Combination 1D}

Finally, MBT and TBT (the negative loadings for Factor 2 in the J-Mode) are related also with spring and mussels' samples, because these BTs show the lower concentrations in this season in these organisms. An interesting finding is the relatively high correlation observed between TBT and DBT in the spring season (Spearman coefficient: $r=0.89, p$ $<0.05)$, which would indicate an active metabolism in mussels, that derive in the biotransformation of TBT in DBT (Furdek et al. 2012). Although these authors focused on another species of mussels, physiology and reproduction strategies are quite comparable since the Mytilus galloprovincialis also belongs to the family Mytilidae as does Brachidontes rodrigezzi. Brachidontes rodriguezii (and Mytilidae species in general) enter the breeding season when the water temperature increases joint to the presence of sufficient food (Gosling, 2003). These conditions are reached in spring and summer at the BBE and also occur during big phytoplankton bloom (Domingues et al. 2005; Guinder et al. 2012). Furthermore, according to Adami et al. (2008) the Brachidontes rodriguezii population shows a high percentage of recruits throughout the year, with a maximum of recruits during the summer. This could be also related with the $\mathrm{Cl}$ observed for the mussels in spring that was the highest in the year, possibly due to 
the increase of nutrients during the phytoplankton bloom (Fig. S1). Correlation among DBT and MBT was not significant, which could indicate that part of the DBT could be eliminated from the mussel (depuration) before being degraded to MBT or that the metabolism of degradation of DBT is slower (Furdek et al. 2012).

The second core element

The second element of the core array is $[1,1,2,2]$, which has a value of -6.15 (Table 2). As mentioned above, for Factor 1 all the elements of the I-mode (sampling sites) have negative values and the same situation is observed for the elements of the $\mathrm{J}$-mode (butyltins). The possible combinations in this case are the following:

A.(-) Factor 1, I-mode $\times(-)$ Factor 1, J-mode $\times(+)$ Factor 2, K-mode $\times(-)$ Factor 2, Lmode

B.(-) Factor 1, I-mode $\times(-)$ Factor 1, J-mode $\times(-)$ Factor 2, K-mode $\times(+)$ Factor 2, Lmode

The explanation of these combinations is detailed below:

Combination $2 \mathrm{~A}$

This combination links the butyltins of J-mode (particularly the ones with higher and negative contribution, i.e. TBT and DBT) with the winter season (the most positive contribution to Factor 2 in the K-mode) and also with the mussels' samples (the most negative contribution to Factor 2 in the L-mode). It could be noted that, in general, the mussels' samples collected in winter presented the highest concentrations for the three BTs for all the sampling points. A rationale for this fact is that bivalves could have a limited capacity to metabolize the BTs due to the low temperatures recorded in winter, thus generating a bioaccumulation effect (Furdek et al. 2012, Tang et al. 2010). Accordingly, the BDI values calculated for Brachidontes rodriguezii in winter were the highest in the study period, which suggests a TBT accumulation. Similar behavior had previously been observed in the same sampling sites in 2013 (Quintas et al. 2017). Again, the higher amounts of TBT seem to be related with its availability for mussels due 
to the dredging carried out in the autumn of 2014 or to an increased navigation in the Main Channel.

\section{Combination 2B}

The other relationship expressed by the second core element linked the BTs to the autumnal and spring seasons (negative loading values for Factor 2 in the $K$-mode) and with the water samples (the only with positive loading for Factor 2 in the L-mode). Indeed, the overall concentration of BTs (as the sum of TBT, DBT and MBT) in the water samples was higher in all sampling sites in the aforementioned seasons. In autumn, the high total concentration of BTs is mainly due to the contribution of TBT, which possibly appeared as a consequence of the greater maritime traffic, which was also stated by other authors in different study areas (Hoch et al. 2001; Champ et al. 2001). In spring, the large amount of BTs in water is due to DBT, which was determined in high concentrations only in this season, as already discussed. On the other hand, the contribution of MBT to the total BTs concentration is relatively high and shows a little variation throughout the seasons, probably due to the low degradation rate in comparison with the other BTs (Furdek et al. 2012; Wang et al. 2008).

\section{The third core element}

The third element of the core is $[1,1,3,4]$ and has a positive value of 4.10 . Again, two possible combinations could be found:

A.(-) Factor 1, I-mode $\times(-)$ Factor 1, J-mode $\times(+)$ Factor 3, K-mode $\times(-)$ Factor 4, Lmode

B.(-) Factor 1, I-mode $\times(-)$ Factor 1, J-mode $\times(-)$ Factor 3, K-mode $\times(+)$ Factor 4, Lmode

Since this core element has a smaller magnitude than the elements previously discussed, they involve the relationships between the elements with moderate to low contributions to the respective modes. 


\section{Combination $3 \mathrm{~A}$}

This combination links the spring (positive and lower contribution of Factor 3 in the Kmode) to the SPM samples (positive and lower values for Factor 4 in the L-mode). It is noteworthy that all the samples of SPM collected in spring had MBT concentrations under the LOD and the other BTs also showed their lowest concentration in this season. As was mentioned before, the phytoplankton bloom takes place in winter/spring and it has been well established that the growing biomass results not only in the adsorption of pollutants on freshly produced particles but also in higher biodegradation rates (Witt et al. 2002). This phenomenon has been already described in several coastal zones around the world such as the Baltic Sea (Thorsson et al. 2008), the Swedish coasts (Gunnarsson et al. 2000) and the USA Great Lakes (Taylor et al. 1991). Probably for this reason, the highest BDI values for SPM were recorded in spring in all sampling locations (Table S1), with some values close to the unit, due to an accelerated degradation of DBT and MBT.

\section{Combination 3B}

The other combination that could be considered in the third core element associates the autumn (negative and low contributions to Factor 3 in the K-mode) and mussels' samples (negative and low contributions for factor 4 in the L-mode). The relationship among mussels and autumn has been already commented (first core element) and has to do with the low values of BTs recorded. From Table 1 it is possible to observe that in the autumn only MBT was quantified in mussels, with the only exception of TBT in the site S3. In fact, the highest BDI value for mussels in all seasons was 2.12 (Table S1) and was recorded in the sampling point S3 in autumn. This would indicate that the presence of TBT is common in this place, where precisely numerous fishing and recreational vessels are observed on a regular basis. 
The fourth core element is $[2,1,1,3]$ with a negative value of -3.03 . It also has a small magnitude with respect to the first and second core elements so the lower contributions to the loadings are considered. The possible combinations of loading are:

A.(+) Factor 2, I-mode $\times(-)$ Factor 1, J-mode $\times(+)$ Factor 1, K-mode $\times(+)$ Factor 3, Lmode

B.(+) Factor 2, I-mode $\times(-)$ Factor 1, J-mode $\times(-)$ Factor 1, K-mode $\times(-)$ Factor 3, Lmode

C.(-) Factor 2, I-mode $\times(-)$ Factor 1, J-mode $\times(+)$ Factor 1, K-mode $\times(-)$ Factor 3, Lmode

D.(-) Factor 2, I-mode $\times(-)$ Factor 1, J-mode $\times(-)$ Factor 1, K-mode $\times(+)$ Factor 3, Lmode

The following description intend to explain these relationships:

Combination 4A

In this core element the sampling points (I-mode) with positive values are sites S4 and S5, which are related to the MBT (lower and negative for Factor 1 in the $\mathrm{J}$-mode), to the summer (low and positive element in the Factor 1 of $\mathrm{K}$-mode) and to mussels and water samples (lower and positive values of Factor 3 in L-mode). In fact, the sampling point S4 had the highest value of MBT in the whole year for mussels. Also, for water column samples, the S4 point had the highest value for MBT in summer. The BTs degradation process seems to be favored in this sampling site, which is also reflected in the low BDI values (Table S1). On the other hand, the sampling site S5 showed the highest value of TBT in the year for mussels. Indeed, S5 in summer was one of the two points in with a BDI value higher than unity. As mentioned, under the high summer water temperatures a higher metabolic rate of TBT is to be expected. In fact the BDI values for all sampling sites were between 0.02 and 0.68 except for site S5 where the BDI value exceeded unity (1.65). Particularly, this site is located in the inner part of the estuary and mainly in 
summer, have small recreational and fishing vessels. Therefore, probably, the mussels from this site have probably been more exposed to TBT.

\section{Combination 4B}

In this combination, the same sampling points (S4 and S5) appear related to winter season (the lower and negative values for Factor 1 in the K-mode) and to the sediment samples (the only negative element for factor 3 in the L-mode). These sites were the ones with the highest concentration of MBT in the season. This fact and the low value of BDI would indicate an efficient degradation process of the BTs.

\section{Combination 4C}

Another important relationship found in the analysis of the fourth core element is the linkage of sampling point S3 (negative value for Factor 2 in the I-mode) with MBT concentrations (as already mentioned, the lower and negative contribution of Factor 1 to the J-mode) with summer (positive and lower contribution for Factor 1 in the K-mode) and sediment samples (the negative element of Factor 3 in the L-mode), which is expected since this sampling point showed the highest MBT concentration in summer for sediment samples, which could be related to an active biological degradation of BTs at this location.

\section{Combination 4D}

The last relationship linked the sampling point S3 (again, the negative element of Factor 2 in the I-mode), the MBT (lower and negative contribution of Factor 1 to the J-mode), the winter (lower and negative loading for Factor 1 in the K-mode) and the mussels and water samples (positive and lower contribution of Factor 3 in the L-mode), and the relationship is not clear enough, but could be associated to the relatively large BDI value, mainly in the water samples, evidenced in the low concentration of MBT (and high concentration of TBT) in this sampling site in winter. 


\section{Partitioning of TBT between different compartments}

Sorption is considered as one of the most important processes responsible for the reduction of the concentrations and toxicity of organotin compounds in the marine environment (Fent, 1996). So, apparent distribution coefficients for sediment-water $\left(k_{\frac{s}{w}}\right)$, mussels-water $\left(k_{\frac{m}{w}}\right)$, mussel-sediment $\left(k_{\frac{m}{s}}\right)$, mussels-SPM $\left(k_{\frac{m}{S P M}}\right)$, water-SPM $\left(k_{\frac{m}{S P M}}\right)$ and sediment-SPM $\left(k_{\frac{s}{M P S}}\right)$ were calculated as the ratio of the TBT concentrations in the different matrices, in order to assess the distribution among seawater, sediments, mussels and SPM (Table 3).

The coefficients $k_{\frac{m}{w}}, k_{\frac{m}{s}}$ and $k_{\frac{m}{S P M}}$ can be used to evaluate the ability of mussels to concentrate TBT from water, sediment and SPM, respectively. In the current study, $k_{\frac{m}{w}}$ ranged from 0 to 2.09 (mean: 0.47 ), $k_{\frac{m}{s}}$ varied from 0 to 1.03 (mean: 0.24 ) and $k_{\frac{m}{S P M}}$ was found between 0 and 4.47 (mean: 0.89 ). The highest values for the three coefficients were observed in winter. As mentioned above, at low temperatures, the ability to metabolize TBT is reduced and therefore the mussels tend to accumulate this compound (Furdek et al. 2012; Tang et al. 2010). On the other hand, the lowest values for these coefficients were found in autumn (Table 3). The pumping activity of mussels (Brachidontes rodriguezzI) is clearly reduced at high TBT burdens, which also may lead to a decrease in the TBT uptake efficiency (Choi et al. 2009; Quintas et al. 2017). In autumn, the levels of TBT in water were found between 168 and $397 \mathrm{ng} \mathrm{Sn} \mathrm{L}^{-1}$, while the presence of TBT could not be detected in the mussel samples. The TBT concentrations present in the water column exceed the upper EAC value (0.62 $\mathrm{ng} \mathrm{Sn} \mathrm{L^{-1 } )}$ (OSPAR 2004) and therefore certain biological effects are probable for some species located in the area that is in contact with this water. In accordance with the average values obtained, the Brachidontes rodriguezzi seem to bioaccumulate TBT through sediment, water and, to a lesser extent, from SPM. 
The distribution of TBT between dissolved and particulate phase is the main factor which determines its bioavailability for degradation by microorganisms, and, on the other hand, it determines its deposition into the sediments (Gao et al. 2019). In this sense, $k_{\frac{s}{w}}$ values ranged from 0.12 to 3.46 (mean: 0.87 ) and $k_{\frac{s}{S P M}}$ varied between 0 and 3.26 (mean: 0.63 ). These values were very similar, indicating that TBT could be transferred to the sediments from both water and SPM. On the other hand, $k_{\frac{w}{S P M}}$ coefficient presented a wide range (from 0.06 to 12.32 , average: 1.98 ), indicating that the SPM has a high sorption capacity and does not reach the equilibrium with seawater (Choi et al. 2009). The values of $k \frac{w}{S P M}$ suggest that almost all the dissolved TBT is adsorbed on the suspended particles and could then accumulate in the sediments (Ritsema et al. 1991).

\section{Conclusions}

This study evaluated, for the first time, the distribution and accumulation of BTs throughout the BBE in a comprehensive analysis performed in both temporal and spatial domains. Chemometric tools, such as Tucker4 model, made it possible to deeply analyze, visualize and interpret the information hidden in the data tables and to find out the relationships among BTs, sampling sites, seasons and the environmental matrices, including water column, sediments, SPM and native mussels. The results pointed out that all compartments were impacted by the presence of the three BTs, which showed a quite homogeneous distribution along the estuary, even though the use of TBT was banned since September 2008. The presence of these compounds in BBE can have different origins. That is, industrial waste from the PVC plant, the resuspension of sediments or, as mentioned, the leaching of TBT present in antifouling paints that have not been properly removed before the use of TBT-free paints. Therefore, it is necessary to further monitor and assess BTs in BBE, and to continue to restrict the use of TBT to protect the aquatic environment. This fact highlights the importance of the pollutant transport due to tidal dynamics and other anthropic factors such as the periodic dredging 
that could remobilize the contaminants trapped in the sediments. Moreover, other factors such as phytoplankton bloom undoubtedly affect the degradation and distribution of BTs in the different environmental compartments. Furthermore, the apparent distribution coefficients also reveal that TBT bioaccumulates through the sediment, water and, to a lesser extent, through the SPM. On the other hand, SPM seems to play a critical role as a vector for BTs deposition in sediments.

\section{Acknowledgements}

This work was supported by a doctoral grant funded by the National Council of Scientific and Technological Research (CONICET-Argentina) [PIP D-738 2011]; the National Agency for Scientific and Technological Promotion (ANPCyT) [PICT 2015-0709, PICT 2012-2494] and the Universidad Nacional del Sur (UNS) [PGI 24/Q054]. This research was part of the Ph.D. thesis of Pamela Y. Quintas.

\section{Declarations}

Funding: It is detailed in the acknowledgments

Conflicts of interest/Competing interests: All authors declare that they have no conflict of interest related to this study

Availability of data and material (data transparency): The data are in the manuscript or in the Supplementary Material. If you need more data or information we will give it to you without inconvenience

Code availability: Not applicable

Authors' contributions:

Pamela Y. Quintas: Conceptualization, Methodology, Formal analysis, Investigation, Writing - original draft, Visualization, Software

Andrés H. Arias: Investigation, Writing - review \& editing, Funding acquisition, Supervision.

Mónica B. Alvarez: Writing - review \& editing. 
Claudia E. Domini: Writing - review \& editing.

Mariano Garrido: Conceptualization, Writing - review \& editing, Funding acquisition, Supervision, Software

Jorge E. Marcovecchio: Writing - review \& editing, Supervision, Funding acquisition

\section{References}

Abraham M, Westphal L, Hand I, Lerz A, Jeschek J, Bunke D, Leipe T, Schulz-Bull D (2017) TBT and its metabolites in sediments: Survey at a German coastal site and the central Baltic Sea. Mar. Pollut. Bull. 121, 404-410. https://doi.org/10.1016/j.marpolbul.2017.06.020

Adami ML, Tablado A, Sador M.A (2008) Population dynamics of the intertidal lid Brachidontes rodriguezii (Bivalvia) on a rocky shore. Thalassas 24, 21-27.

Al-shatri MA, Nuhu AA, Basheer C, Al-Arfaj A, Al-Tawabini B (2015) Assessment of tributyltin and triphenyltin compounds and their main degradation products in Saudi coastal waters. Arab. J. Sci. Eng. 40, 2959-2967.

Álvarez MB, Garrido M, Lista AG, Fernández Band BS (2008) Three-way multivariate analysis of metal fractionation results from sediment samples obtained by different sequential extraction procedures and ICP-OES. Anal. Chim. Acta 620, 34-43. https://doi.org/10.1016/j.aca.2008.05.035

APHA, AWWA, WEF, (1998) Standard Methods for the Examination of Water and Wastewater. Clesceri, L.S., Greenberg, A.E., Eaton, A.D. (Eds.), 20th Edition, American Public Health Association, Washington, USA, 996 pp.

Arrieche D, Licet B, García N, Lodeiros C, Prieto A (2002) Índice de condición, gonádico y de rendimiento del mejillón marrón Perna perna (Bivalvia: Mytilidae): del Morro de Guarapo-Venezuela. Interciencia 27, 613-619. 
Basheeru KA, Okoro HK, Adekola FA, Abdus-Salam N (2020) Speciation and quantification of organotin compounds in Lagos harbour, Nigeria. Int. J. Environ. Anal. Chem. 1-20. https://doi.org/10.1080/03067319.2020.1849647

Batista RM, Castro IB, Fillmann G (2016) Imposex and butyltin contamination still evident in Chile after TBT global ban. Sci. Total Environ. 566, 446-453. https://doi.org/10.1016/j.scitotenv.2016.05.039.

Baumard P, Budzinski H, Michon Q, Garrigues T, Burgeot T, Bellocq J (1998) Origin and bioavailability of PAHs in the Mediterranean Sea from mussel and sediment records. Estuar. Coast. Shelf Sci. 47, 77-90. https://doi.org/ 10.1006/ecss.1998.0337 Berg M, Arnold CG, Müller SR, Mühlemann J, Schwarzenbach RP (2001) Sorption and desorption behavior of organotin compounds in sediment-pore water systems. Environ. Sci. Technol. 35, 3151-3157. https://doi.org/10.1021/es010010f

Bernat P, Długoński J (2006) Acceleration of tributyltin chloride (TBT) degradation in liquid cultures of the filamentous fungus Cunninghamella elegans. Chemosphere 62, 38. https://doi.org/10.1016/j.chemosphere.2005.04.045

Bravo ME, Aliotta S, Fiori S, Ginsberg S (2018) Distribution, vertical position and ecological implications of shallow gas in Bahía Blanca estuary (Argentina). Estuar. Coast. Shelf Sci. 202, 222-231. https://doi.org/10.1016/j.ecss.2018.01.007

Bro R. Multi-way analysis in the food industry: models, algorithms, and appli-cations, in: Ph.D. Thesis, University of Amsterdam, Amsterdam, 1998.

Bro R, Anderson C.A., N-way Toolbox for MATLAB (TM), (2013) http://www.models.life.ku.dk/nwaytoolbox/download.

Burgeot T, Vincent F, Bocquene G, His E, Quiniou F, Galgani F (2001) Monitoring of biological effects of pollutants: field application. Chapter: 7, Biomarkers in marine organisms; a practical approach. P. Garrigues H. Barth, C.H. Walker and J.F. Narbonne, Elsevier. pp. 179-213 
Castro ÍB, Fillmann G (2012) High tributyltin and imposex levels in the commercial muricid Thais chocolata from two Peruvian harbor areas. Environ. Toxicol. Chem. 31, 955-960. https://doi.org/10.1002/etc.1794.

Ceulemans E, Kiers HA (2006) Selecting among three-mode principal component models of different types and complexities: A numerical convex hull based method. BRIT J. Math. Stat. Psy. 59, 133-150. https://doi.org/10.1348/000711005X64817

Champ MA (2001) The status of the treaty to ban TBT in marine antifouling paints and alternatives. In Proceedings of the 24th UJNR (US/Japan) Marine Facilities Panel Meeting, Hawaii.

Chen Z, Chen L, Chen C, Huang Q, Wu L, Zhang W (2017) Organotin Contamination in Sediments and Aquatic Organisms from the Yangtze Estuary and Adjacent Marine Environments. Environ. Eng. Sci. 34, 227-235. https://doi.org/10.1089/ees.2016.0370 Choi M, Choi HG, Moon HB, Kim GY (2009) Spatial and temporal distribution of tributyltin (TBT) in seawater, sediments and bivalves from coastal areas of Korea during 20012005. Environ. Monit. Assess.151, 301-310. https://doi.org/10.1007/s10661-008-0271-0 Commendatore MG, Esteves JL (2004) Natural and anthropogenic hydrocarbons in sediments of the Chubut River (Patagonia, Argentina). Mar. Pollut. Bull. 48, 910-918. https://doi.org/10.1016/j.marpolbul.2003.11.015

Deng T, Wu L, Gao JM, Zhou B, Zhang YL, Wu WN, Tang ZH, Jiang WC, Huang WL (2018) Occurrence and health risk assessment of organotins in waterworks and the source water of the Three Gorges Reservoir Region, China. Environ. Sci. Pollut. R. 25, 15019-15028. https://doi.org/10.1007/s11356-018-1704-0

Díez S, Abalos M, Bayona JM (2002) Organotin contamination in sediments from the Western Mediterranean enclosures following 10 years of TBT regulation. Water Res. 36, 905-918. https://doi.org/10.1016/S0043-1354(01)00305-0

Diez S, Lacorte S, Viana P, Barceló D, Bayona JM (2005) Survey of organotin compounds in rivers and coastal environments in Portugal 1999-2000. Environ. Pollut. 136, 525-536. https://doi.org/10.1016/j.envpol.2004.12.011 
Domingues RB, Barbosa A, Galvão H (2005) Nutrients, light and phytoplankton succession in a temperature estuary (the Guadiana, south-western Iberia). Estuar. Coast. Shelf Sci. 64, 249-260. https://doi.org/10.1016/j.ecss.2005.02.017 d’Orbigny AD (1842) Brachidontes rodriguezii, Voyage dans l'Amérique Méridionale. P. Bertrand, Paris, pp. 83-85

dos Santos, D.M., Turra, A., de Marchi, M.R.R., Montone, R.C., (2016) Distribution of butyltin compounds in Brazil's southern and southeastern estuarine ecosystems: assessment of spatial scale and compartments. Environ. Sci. Pollut. Res. 23, 1615216163. https://doi.org/10.1007/s11356-016-6720-3

Dowson PH, Bubb JM, Lester JN (1996) Persistence and degradation pathways of tributyltin in freshwater and estuarine sediments. Estuar. Coast. Shelf Sci.42, 551-562. https://doi.org/10.1006/ecss.1996.0036

Dutto MS, Genzano GN, Schiariti A, Lecanda J, Hoffmeyer MS, Pratolongo PD (2017) Medusae and ctenophores from the Bahía Blanca Estuary and neighboring inner shelf (Southwest Atlantic Ocean, Argentina). Mar. Biodivers. Rec. 10, 14. https://doi.org/10.1186/s41200-017-0114-1

El Hadj Z, Boutiba Z, Meghabar R (2016) Trace analysis of butyltin compounds in seawater of some west Algerian harbors by gas chromatography-mass spectrometry. Environ. Forensics, 17, 183-189. https://doi.org/10.1080/15275922.2016.1163624

EURACHEM (1998) The fitness for purpose of analytical methods. A laboratory guide to method validation and related topics. LGC (Teddington) Ltd, London, p 75

Fang L, Borggaard OK, Christensen JH, Holm PE, Hansen HCB (2012) Adsorption of mono-and di-butyltin by a wheat charcoal: $\mathrm{pH}$ effects and modeling. Chemosphere 89 , 863-868. https://doi.org/10.1016/j.chemosphere.2012.05.010

Fang L, Xu C, Li J, Borggaard OK, Wang D (2017) The importance of environmental factors and matrices in the adsorption, desorption, and toxicity of butyltins: a review. Environ. Sci. Pollut. Res. 1-15. https://doi.org/10.1007/s11356-017-8449-z 
Farrington JW, Tripp BW (1995) International Mussel Watch Project, Coastal Chemical Contaminant Monitoring Using Bivalves. TABLE 1: Attributes of Bivalves as Sentinel Organisms

Fent K (1996) Ecotoxicology of organotin compounds. Crit. Rev. 26, 3-117. https://doi.org/10.3109/10408449609089891

Filipkowska A, Lubecki L (2016) Endocrine disruptors in blue mussels and sediments from the Gulf of Gdańsk (Southern Baltic). Environ. Sci. Pollut. Res. 23, 13864-13876. https://doi.org/10.1007/s11356-016-6524-5

Freije RH, Spetter CV, Marcovecchio JE, Popovich CA, Botté SE, Negrín V, Arias A, Delucchi F, Asteasuain RO (2008) Water chemistry and nutrients of the Bahía Blanca Estuary. Perspectives on integrated coastal zone Management in South America, 24154.

Furdek M, Vahčič M, Ščančar J, Milačič R, Kniewald G, Mikac N (2012) Organotin compounds in seawater and Mytilusgallo provincialis mussels along the Croatian Adriatic coast. Mar. Pollut. Bull. 64, 189-199. https://doi.org/10.1016/j.marpolbul.2011.12.009 Gadd GM (2000) Microbial interactions with tributyltin compounds: detoxification, accumulation, and environmental fate. Sci. Total Environ. 258, 119-127. https://doi.org/10.1016/S0048-9697(00)00512-X

Gao JM, Chen XL, Ren CR, Qiu H, Zhang K, Guo JS, Tang Z.H, Wu WN, Zhang YL (2019) Organotins in the aquatic media of secondary anabranches in the Three Gorges $\begin{array}{llll}\text { Reservoir } \quad \text { Region, } & \text { China. } & \text { Chemosphere } 242 .\end{array}$ https://doi.org/10.1016/j.chemosphere.2018.10.204

Gomez-Ariza JL, Morales E, Giraldez I (1999) Uptake and elimination of tributyltin in clams, Venerupis decussata. Mar. Environ. Res.47, 399-413. https://doi.org/10.1016/S0141-1136(98)00129-9

Gosling, EM 2003. Bivalve Molluscs: Biology, ecology and culture. Fishing News Books. An imprint of Blackwell Science. MPG Books Ltd. Bodmin, Cornwall, Great Britain. pp. 
Grasshoff K (1976) Filtration and Storage. In: Methods of Seawater Analysis, Verlag Chemie, Weinheim, New York: 21-24.

Grecco LE, Gómez EA, Botté SE, Marcos AO, Marcovecchio JE, Cuadrado DG (2011) Natural and anthropogenic heavy metals in estuarine cohesive sediments: geochemistry and bioavailability. Ocean Dyn. 61 (2e3), 285e293. https://doi.org/10.1007/s10236-0100354-7

Guinder VA, López-Abbate MC, Berasategui AA, Negrin VL, Zapperi G, Pratolongo PD, Fernández Severini MD, Popovich CA (2015) Influence of the winter phytoplankton bloom on the settled material in a temperate shallow estuary. Oceanologia 57, 50-60. https://doi.org/10.1016/j.oceano.2014.10.002

Guinder VA., Popovich CA,. Molinero JC, Marcovecchio JE (2012) Phytoplankton summer bloom dynamics in the Bahia Blanca Estuary in relation to changing environmental conditions. Cont. Shelf Res. 52, 150-158. https://doi.org/10.1016/j.csr.2012.11.010

Gunnarsson J, Björk M, Gilek M, Granberg M, Rosenberg R (2000) Effects of eutrophication on contaminant cycling in marine benthic systems. AMBIO: J. Hum. Environ. Health Promot. 29, 252-259. https://doi.org/10.1579/0044-7447-29.4.252

Hoch M (2001) Organotin compounds in the environment-an overview. Appl. Geochem. 16, 719-743. https://doi.org/10.1016/S0883-2927(00)00067-6.

Hoch M, Alonso-Azcarate J, Lischick M (2003) Assessment of adsorption behavior of dibutyltin (DBT) to clay-rich sediments in comparison to the highly toxic tributyltin (TBT). Environ. Pollut. 123, 217-227. https://doi.org/10.1016/S0269-7491(02)00402-5 Hongxia L, Guolan H, Shugui D (1996) Transport of butyltins at the water-air interface and the adsorptive behavior of tributyltin in the surface microlayer. Environ. Toxicol. Chem. https://doi.org/10.1080/02772249609358340

IMO (2001) International Maritime Organization. International convention on the control of harmful anti-fouling systems on ships. 
Kim NS, Shim WJ, Yim UH, Hong SH, Ha SY, Han GM, Shin KH (2014) Assessment of TBT and organic booster biocide contamination in seawater from coastal areas of South Korea. Mar. Pollut. Bull. 78, 201-208. https://doi.org/10.1016/j.marpolbul.2013.10.043 Lagerström M, Strand J, Eklund B, Ytreberg E (2017) Total tin and organotin speciation in historic layers of antifouling paint on leisure boat hulls. Environ. Pollut. 220, 13331341. https://doi.org/10.1016/j.envpol.2016.11.001

Lam NH, Jeong HH, Kang SD, Kim DJ, Ju MJ, Horiguchi T, Cho HS (2017) Organotins and new antifouling biocides in water and sediments from three Korean Special Management Sea Areas following ten years of tributyltin regulation: contamination profiles and risk assessment. Mar. Pollut. Bull. 121, 302-312. https://doi.org/10.1016/j.marpolbul.2017.06.026

Lau DC, Leung KM (2004) Feeding physiology of the carnivorous gastropod Thais clavigera (Kuster): do they eat "soup"? J. Exp. Mar. Biol. 312, 43-66. https://doi.org/10.1016/j.jembe.2004.06.002

Leardi R, Armanino C, Lanteri S, Alberotanza L (2000) Three-mode principal component analysis of monitoring data from Venice lagoon. J. Chemom. 14, 187-195. https://doi.org/10.1002/1099-128X(200005/06)14:3<187::AID-CEM593>3.0.CO;2-0

Liu LL, Wang JT, Chung KN, Leu MY, Meng PJ (2011) Distribution and accumulation of organotin species in seawater, sediments and organisms collected from a Taiwan mariculture area. Mar. Pollut. Bull. 63, 535-540. https://doi.org/10.1016/j.marpolbul.2011.02.003

Maciel DC, Castro ÍB, de Souza JRB, Yogui GT, Fillmann G, Zanardi-Lamardo E (2018) Assessment of organotins and imposex in two estuaries of the northeastern Brazilian coast. Mar. Pollut. Bull. 126, 473-478. https://doi.org/10.1016/j.marpolbul.2017.11.061 Marinho CH, Giarratano E, Domini CE, Garrido M, Gil MN (2019) Potential mobility assessment of metals in salt marsh sediments from San Antonio Bay. Environ. Monit. Assess. 191, 723. https://doi.org/10.1007/s10661-019-7895-0 
Martínez ML, Piol MN, Nudelman NS, Guerrero NRV (2017) Tributyltin bioaccumulation and toxic effects in freshwater gastropods Pomacea canaliculata after a chronic exposure: field and laboratory studies. Ecotoxicology 26, 691-701. https://doi.org/10.1007/s10646-017-1801-8

Michel P, Averty B, Andral B, Chiffoleau JF, Galgani F (2001) Tributyltin along the coasts of Corsica (Western Mediterranean): a persistent problem. Mar. Pollut. Bull. 42:11281132. https://doi.org/10.1016/ S0025-326X(01)00101-1

Ohji M, Arai T, Miyazaki N (2007) Comparison of organotin accumulation in the masou salmon Oncorhynchusmasou accompanying migratory histories. Estuar. Coast Shelf Sci. 72, 721-731. https://doi.org/10.1016/j.ecss.2006.12.004.

Okoro HK, Fatoki OS, Adekola FA, Ximba BJ, Snyman RG (2016) Spatio-temporal variation of organotin compounds in seawater and sediments from Cape Town harbour, South Africa using gas chromatography with flame photometric detector (GC-FPD). Arab. J. Chem. 9, 95-104. https://doi.org/10.1016/j.arabjc.2013.05.014

Orban E, Di Lena G, Nevigato T, Casini I, Marzetti A, Caproni R (2002) Seasonal changes in meat content, condition index and chemical composition of mussels (Mytilus galloprovincialis) cultured in two different Italian sites. Food Chem. 77, 57-65. https://doi.org/10.1016/S0308-8146(01)00322-3.

OSPAR, 2004. OSPAR/ICES Workshop on the evaluation and update of background reference concentrations $(\mathrm{B} / \mathrm{RCs})$ and ecotoxicological assessment criteria (EACs) and how these assessment tools should be used in assessing contaminants in water, sediment and biota, Final report, OSPAR commission.

Perillo GME, Piccolo MC (1991) Tidal response in the Bahía Blanca estuary, Argentina.

J. Coast. Res. 7, 437-449. 〈http://www.jstor.org/stable/4297848〉.

Quintas PY, Arias AH, Oliva AL, Domini CE, Alvarez MB, Garrido M, Marcovecchio JE (2017) Organotin compounds in Brachidontes rodriguezii mussels from the Bahía Blanca Estuary, Argentina. Ecotox. Environ. Safe. 145, 518-527. https://doi.org/10.1016/j.ecoenv.2017.07.052 
Quintas PY, Oliva AL, Alvarez MB, Arias AH, Domini CE, Garrido M, Marcovecchio JE, (2018) Fast and Feasible Ultrasound-Assisted Pretreatment for the Determination of Organotin Compounds in Environmental Samples. Arch. Environ. Contam. Toxicol. 111. https://doi.org/10.1007/s00244-017-0494-6

Quintas PY, Alvarez MB, Arias AH, Garrido M, Marcovecchio JE (2019) Spatiotemporal distribution of organotin compounds in the coastal water of the Bahía Blanca estuary (Argentina). Environ. Sci. Pollut. Res. 26(8), 7601-7613. https://doi.org/10.1007/s11356019-04181-7

Ritsema R, Laane RWPM, Donard OFX (1991) Butyltins in marine waters of the Netherlands in 1988 and 1989; concentrations and effects. Mar. Environ. Res. 32, 243260. https://doi.org/10.1016/0141-1136(91)90046-B

Seligman PF, Maguire RJ, Lee RF, Hinga KR, Valkirs AO, Stang PM (1996) Persistence and Fate of Tributyltin in Aquatic Ecosystems. Organotin 429-457. https://doi.org/10.1007/978-94-009-1507-7_21

Seligman PF, Valkirs AO, Lee RF (1986) Degradation of tributyltin in San Diego Bay, California, waters. Environ. Sci. Technol. 20, 1229-1235. https://doi.org/10.1021/es00154a006

Simonetti P, Botté SE, Marcovecchio JE (2017) Occurrence and spatial distribution of metals in intertidal sediments of a temperate estuarine system (Bahía Blanca, Argentina). Environ. Earth Sci. 76, 1-12. https://doi.org/10.1007/s12665-017-6975-0

Singh KP, Malik A, Basant N, Singh VK, Basant A (2007) Multi-way data modeling of heavy metal fractionation in sediments from Gomti River (India). Chemometr. Intell. Lab. Syst. 87, 185-193. https://doi.org/10.1016/j.chemolab.2007.01.001

Sousa A, Ikemoto T, Takahashi S, Barroso C, Tanabe S (2009) Distribution of synthetic organotins and total tin levels in Mytilusgalloprovincialis along the Portuguese coast. Mar. Pollut. Bull. 58, 1130-1136. https://doi.org/10.1016/j.marpolbul.2009.04.007

Spetter CV, Buzzi NS, Fernández EM, Cuadrado DG, Marcovecchio JE (2015) Assessment of the physicochemical conditions sediments in a polluted tidal flat colonized 
by microbial mats in Bahía Blanca Estuary (Argentina). Mar. Pollut. Bull. 91, 491-505. https://doi.org/10.1016/j.marpolbul.2014.10.008

Stanimirova I, Kita A, Malkowski E, John E, Walczak B (2009). N-way exploration of environmental data obtained from sequential extraction procedure. Chemometr. Intell. Lab. Syst. 96, 203-209. https://doi.org/10.1016/j.chemolab.2009.02.004

Taylor WD, Carey JH, Lean DRS, McQueen DJ (1991) Organochlorine concentrations in the plankton of lakes in southern Ontario and their relationship to plankton biomass. Can. J. Fish. Aquat. Sci.48, 1960-1966. https://doi.org/10.1139/f91-233

Tang $\mathrm{CH}$, Hsu CH, Wang WH (2010) Butyltin accumulation in marine bivalves under field conditions in Taiwan. Mar. Environ. Res. 70, 125-132. https://doi.org/10. 1016/j.marenvres.2010.03.011.

Thompson M, Ellison SL, Wood R (2002) Harmonized guidelines for single-laboratory validation of methods of analysis (IUPAC Technical Report). Pure Appl. Chem. 74, 835855. https://doi.org/10.1351/pac200274050835

Thorsson MH, Hedman JE, Bradshaw C, Gunnarsson JS, Gilek M (2008) Effects of settling organic matter on the bioaccumulation of cadmium and BDE-99 by Baltic Sea benthic invertebrates. Mar. Environ. Res. 65, 264-281. https://doi.org/10.1016/j.marenvres.2007.11.004

van Gessellen N, Bouwman H, Averbuj A (2018) Imposex assessment and tributyltin levels in sediments along the Atlantic coast of South Africa. Mar. Environ. Res. 142, $32-$ 39. https://doi.org/10.1016/j.marenvres.2018.09.016

Vidal JL, Vega AB, Arrebola FJ, González-Rodríguez MJ, Sanchez MC, Frenich AG, (2003) Trace determination of organotin compounds in water, sediment and mussel samples by low-pressure gas chromatography coupled to tandem mass spectrometry. Rapid Commun. Mass Spectrom. 17, 2099-2106. https://doi.org/10.1002/rcm.1152 Wang $\mathrm{X}$, Hong $\mathrm{H}$, Zhao D, Hong $\mathrm{L}$ (2008) Environmental behavior of organotin compounds in the coastal environment of Xiamen, China. Mar. Pollut. Bull. 57, 419-424. https://doi.org/10.1016/j.marpolbul.2008.04.034 
Witt G (2002) Occurrence and transport of polycyclic aromatic hydrocarbons in the water bodies of the Baltic Sea. Mar. Chem. 79, 49-66. https://doi.org/10.1016/S03044203(02)00035-X

\section{Figure Caption:}

Fig.1. Map showing the study area and the sampling points. S1: Rosales Harbor (shiprepair yard); S2 and S3: Ingeniero White Harbor (S2: near thermoelectric plant, S3: fishing and recreational zone); S4: Galván Harbor (industrial harbor, gas, and oil loading buoy); S5: Cuatreros Harbor (fishing and recreational port); and S6: Villarino Viejo (rural zone).

Fig. 2. (a) Loading plots for the I-mode (sampling sites), (b) loading plots for the J-mode (BTs), (c)-(h) loading plots for the K-mode (season) and (i)-(n) loading plots for the Lmode (compartments) obtained by Tucker4 model.

\section{Supplementary material}

Fig S1. Seasonal variation of the condition index for all the sites studied.

Fig. S2. Deviance plot and its st- coefficients for Tucker4 models of different complexity.

Fig S3. Determination of butyltin compounds in a) standar solution; b) mussels samples (S5, winter) and c) water sample (S6, winter) by GC-MS. Column: HP-5MS fused silica (30 m; $0.25 \mathrm{~mm}$ i.d.; $0.25 \mu \mathrm{m}$ ); carrier helium at flow rate of $1 \mathrm{~mL} \mathrm{~min}-1$; split ratio $60: 1$; injector and ion source temperatures $200{ }^{\circ} \mathrm{C}$ and $210{ }^{\circ} \mathrm{C}$, respectively. Temperature program, $55^{\circ} \mathrm{C}$ for $1 \mathrm{~min}$, then $20^{\circ} \mathrm{C} \min -1$ up to $200^{\circ} \mathrm{C}, 200^{\circ} \mathrm{C}$ for $5 \mathrm{~min}$; injection volume $1 \mu \mathrm{L}$. Peak identification: MBT: monobutyltin; DBT: dibutyltin; TPrT: tripropyltin (surrogate standar); TBT: tributyltin and TeBT: Tetrabutyltin (internal standar) 
Table 1. Mean values for the BTs concentrations in different compartments taken in the BBE

\begin{tabular}{|c|c|c|c|c|c|c|c|c|c|c|c|c|c|}
\hline \multirow{2}{*}{$\begin{array}{c}\text { Seaso } \\
\mathbf{n}\end{array}$} & \multirow{2}{*}{$\begin{array}{c}\text { Site } \\
\mathbf{S}\end{array}$} & \multicolumn{3}{|c|}{ Sediments (ng Sn g $^{-1}$ dry wt) } & \multicolumn{3}{|c|}{ Mussels (ng Sn g-1 dry wt) } & \multicolumn{3}{|c|}{ SPM (ng Sn L-1) } & \multicolumn{3}{|c|}{ Water column (ng Sn $\mathrm{L}^{-1}$ ) } \\
\hline & & TBT & DBT & MBT & TBT & DBT & MBT & TBT & DBT & MBT & TBT & DBT & MBT \\
\hline \multirow{6}{*}{$\underset{r}{\text { Summe }}$} & S1 & $28.8(1.0)$ & $33.2(1.8)$ & $263(5)$ & $51.6(1.6)$ & $99.2(9.9)$ & $22.3(3.0)$ & $221(9)$ & $297(22)$ & $374(62)$ & $75.1(2.4)$ & n.q. & $315(23)$ \\
\hline & S2 & $61.7(0.7)$ & $36.9(1.9)$ & $149(2)$ & $18.6(0.7)$ & $60.8(2.5)$ & n.q. & $241(20)$ & $367(26)$ & n.q. & $68.4(2.8)$ & n.q. & $308(24)$ \\
\hline & S3 & $259(14)$ & $104(5.7)$ & $435(25)$ & $66.1(2.7)$ & $93.2(2.5)$ & n.q. & $242(16)$ & $305(14)$ & n.q. & $74.9(4.2)$ & n.q. & $414(12)$ \\
\hline & S4 & $38.4(14.1)$ & $42.4(2.2)$ & $155(9)$ & n.q. & $20.7(0.9)$ & $51.4(2.0)$ & $246(17)$ & 334 (27) & $479(20)$ & $65.2(5.1)$ & n.q. & $347(20)$ \\
\hline & S5 & $108(2)$ & $55.8(0.6)$ & $210(9)$ & $118(1)$ & $52.1(1.9)$ & $19.4(0.6)$ & 238 (3) & $392(2)$ & $154(17)$ & $56.5(4.6)$ & n.q. & 308 (18) \\
\hline & S6 & 47.9 (3.9) & $37.3(2.4)$ & $150(5)$ & $9.66(0.04)$ & $22.9(0.9)$ & n.q. & $351(20)$ & $461(8)$ & n.q. & $21.4(0.5)$ & n.q. & $289(10)$ \\
\hline \multirow{6}{*}{$\begin{array}{c}\text { Autum } \\
\mathrm{n}\end{array}$} & $\mathrm{S} 1$ & $29.7(1.2)$ & $67.4(7.5)$ & $463(6)$ & n.q. & n.q. & $22.6(2.4)$ & $63.8(1.6)$ & $100(14)$ & $740(30)$ & $216(19)$ & n.q. & 317 (18) \\
\hline & $\mathrm{S} 2$ & $142(11)$ & $33.3(5.0)$ & $611(9)$ & n.q. & n.q. & $19.1(1.4)$ & $54.4(3.4)$ & $128(11)$ & $91.7(2.4)$ & 197 (17) & n.q. & 647 (29) \\
\hline & S3 & $242(15)$ & $97.3(7.4)$ & $831(8)$ & $82.4(0.8)$ & n.q. & $37.0(3.9)$ & $74.7(4.8)$ & $87.0(4.1)$ & $82.7(4.6)$ & 227 (15) & n.q. & 363 (19) \\
\hline & S4 & $46.2(4.4)$ & $40.1(4.3)$ & $123(7)$ & n.q. & n.q. & $17.7(1.8)$ & $51.8(2.5)$ & $94.4(12.6)$ & $125(24)$ & $296(20)$ & n.q. & 337 (22) \\
\hline & S5 & $31.2(2.6)$ & $48.5(2.2)$ & n.q. & n.q. & n.q. & $16.9(2.1)$ & $42.2(2.3)$ & $56.7(2.8)$ & $59.3(6.4)$ & $186(12)$ & n.q. & $414(12)$ \\
\hline & S6 & $102(3)$ & $38.3(2.5)$ & $5.56(0.12)$ & n.q. & n.q. & $17.7(0.3)$ & $31.4(4.3)$ & $62.1(1.7)$ & n.q. & $387(25)$ & n.q. & $315(8)$ \\
\hline \multirow{6}{*}{ Winter } & S1 & n.q. & $10.0(0.6)$ & $47.0(6.2)$ & 79.7 (8.3) & $77.0(8.1)$ & $47.8(4.0)$ & $293(3)$ & $166(8)$ & n.q. & $105(10)$ & n.q. & $455(5)$ \\
\hline & S2 & n.q. & $2.70(0.15)$ & $117(1)$ & $62.1(8.9)$ & $100(4)$ & $41.0(2.0)$ & $80.7(5.0)$ & $334(27)$ & $22.2(2.0)$ & $43.5(10.9)$ & n.q. & $329(20)$ \\
\hline & S3 & n.q. & $15.1(1.6)$ & $196(7)$ & $70.8(6.7)$ & $64.5(0.4)$ & $14.3(1.0)$ & $92.1(2.7)$ & 167 (19) & n.q. & $88.5(5.1)$ & n.q. & $354(4)$ \\
\hline & $\mathrm{S} 4$ & $13.9(1.8)$ & $11.6(0.9)$ & $417(7)$ & $62.1(3.1)$ & $79.3(10.9)$ & $14.0(1.1)$ & - & - & - & $47.8(4.2)$ & n.q. & 356 (16) \\
\hline & S5 & $13.7(4.0)$ & $5.46(1.04)$ & 247 (5) & $59.8(1.2)$ & $51.8(2.4)$ & $29.3(2.1)$ & - & - & - & $112(8)$ & n.q. & $352(12)$ \\
\hline & S6 & n.q. & n.q. & $72.2(6.3)$ & $57.1(4.7)$ & $55.0(2.1)$ & $18.6(1.7)$ & $155(13)$ & 250 (12) & $553(34)$ & $88.5(2.4)$ & n.q. & $370(10)$ \\
\hline \multirow{6}{*}{ Spring } & S1 & n.q. & n.q. & $134(5)$ & $9.11(0.73)$ & $24.0(3.0)$ & $17.5(3.4)$ & $27.4(1.4)$ & $30.3(2.1)$ & n.q. & $22.6(2.3)$ & $288(12)$ & $289(1)$ \\
\hline & $\mathrm{S} 2$ & n.q. & $598(35)$ & $98.5(3.7)$ & $3.48(0.17)$ & $8.17(0.90)$ & $17.3(0.3)$ & $46.2(1.6)$ & $59.1(4.2)$ & n.q. & $58.2(8.2)$ & $333(18)$ & $317(17)$ \\
\hline & S3 & $35.6(2.9)$ & $6.94(0.85)$ & $288(18)$ & $19.6(0.77)$ & $14.0(2.9)$ & $17.7(1.1)$ & $52.3(3.4)$ & $60.8(13.0)$ & n.q. & $54.0(5.6)$ & $510(28)$ & $303(18)$ \\
\hline & S4 & n.q. & $602(6)$ & $47.7(2.4)$ & $2.54(0.02)$ & $4.94(0.9)$ & $18.0(0.8)$ & $38.8(0.6)$ & $46.7(2.6)$ & n.q. & $84.8(8.5)$ & $358(12)$ & $289(7)$ \\
\hline & S5 & n.q. & $782(12)$ & $220(12)$ & $3.30(0.06)$ & $4.75(0.9)$ & $18.3(0.4)$ & $46.6(1.9)$ & $49.3(6.0)$ & n.q. & $55.5(3.6)$ & $260(13)$ & $306(15)$ \\
\hline & S6 & n.q. & n.q. & $243(7)$ & $6.80(0.59)$ & $11.4(0.7)$ & $18.3(1.2)$ & $48.0(2.0)$ & $52.8(8.2)$ & n.q. & $46.0(2.2)$ & $290(13)$ & $294(6)$ \\
\hline
\end{tabular}


Table 2. The first four elements of the core array for the Tucker 4 model $[2,2,4,4]$

\begin{tabular}{ccc}
\hline Core element $[\mathbf{p}, \mathbf{q}, \mathbf{r}, \mathbf{s}]$ & Core value & $\begin{array}{c}\text { Cumulative } \\
\text { explained variance }\end{array}$ \\
\hline$[1,2,1,1]$ & -6.76 & $28.46 \%$ \\
{$[1,1,2,2]$} & -6.15 & $51.97 \%$ \\
{$[1,1,3,4]$} & 4.10 & $62.42 \%$ \\
{$[2,1,1,3]$} & -3.03 & $68.12 \%$ \\
\hline
\end{tabular}


Table 3. Distribution coefficients of TBT between all the compartments studied from BBE.

\begin{tabular}{|c|c|c|c|c|c|c|c|}
\hline Sampling & Sites & $k_{m / S P M}{ }^{\mathbf{a}}$ & $k_{m / W}{ }^{\mathbf{a}}$ & $k_{m / s} b$ & $k_{S / W}{ }^{\mathbf{a}}$ & $k_{W / S P M} b$ & $k_{S / S P M} a$ \\
\hline \multirow{6}{*}{ Summer } & S1 & 0.23 & 0.69 & 1.79 & 0.38 & 0.34 & 0.13 \\
\hline & S2 & 0.08 & 0.27 & 0.30 & 0.90 & 0.28 & 0.26 \\
\hline & S3 & 0.27 & 0.88 & 0.26 & 3.46 & 0.31 & 1.07 \\
\hline & S4 & ---- & ---- & ---- & 0.59 & 0.26 & 0.16 \\
\hline & S5 & 0.50 & 2.09 & 1.09 & 1.92 & 0.24 & 0.46 \\
\hline & S6 & 0.03 & 0.45 & 0.20 & 2.24 & 0.06 & 0.14 \\
\hline \multirow{6}{*}{ Autumn } & S1 & ---- & ---- & ---- & 0.14 & 3.39 & 0.47 \\
\hline & S2 & ---- & ---- & ---- & 0.72 & 3.61 & 2.60 \\
\hline & S3 & 1.03 & 0.36 & 0.34 & 1.07 & 2.85 & 3.04 \\
\hline & S4 & ---- & ---- & ---- & 0.16 & 5.71 & 0.89 \\
\hline & S5 & ---- & ---- & ---- & 0.17 & 4.42 & 0.74 \\
\hline & S6 & ---- & ---- & ---- & 0.26 & 12.32 & 3.26 \\
\hline \multirow{6}{*}{ Winter } & S1 & 0.27 & 0.76 & n.c. & n.c. & 0.36 & ---- \\
\hline & $\mathrm{S} 2$ & 0.77 & 1.43 & n.c. & n.c. & 0.54 & ---- \\
\hline & S3 & 0.77 & 0.80 & n.c. & n.c. & 0.96 & ---- \\
\hline & S4 & * & 1.30 & 4.47 & 0.29 & * & * \\
\hline & S5 & * & 0.53 & 4.37 & 0.12 & * & * \\
\hline & S6 & 0.37 & 0.65 & n.c. & n.c. & 0.57 & ---- \\
\hline \multirow{6}{*}{ Spring } & S1 & 0.33 & 0.40 & n.c. & n.c. & 0.82 & $\begin{array}{l}--- \\
\end{array}$ \\
\hline & S2 & 0.08 & 0.06 & n.c. & n.c. & 1.26 & ---- \\
\hline & S3 & 0.37 & 0.36 & 0.55 & 0.66 & 1.03 & 0.68 \\
\hline & S4 & 0.07 & 0.03 & n.c. & n.c. & 2.19 & ---- \\
\hline & S5 & 0.07 & 0.06 & n.c. & n.c. & 1.19 & ---- \\
\hline & S6 & 0.14 & 0.15 & n.c. & n.c. & 0.96 & ---- \\
\hline
\end{tabular}


a: ng L-1; ; $:$ no units; ----: values close to zero; * Absence of samples; n.c: not possible to calculate 


\section{Figures}

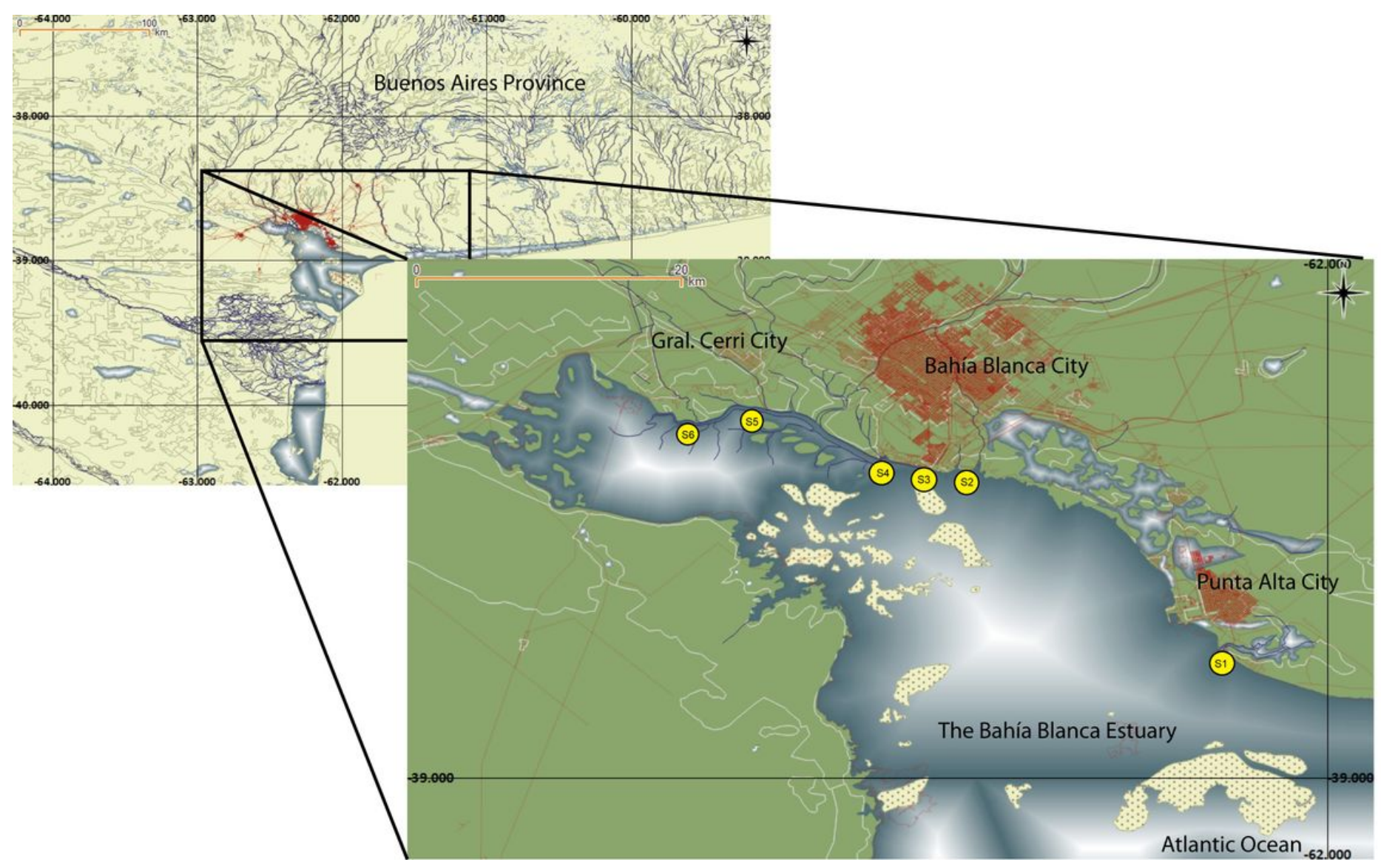

\section{Figure 1}

Map showing the study area and the sampling points. S1: Rosales Harbor (ship-repair yard); S2 and S3: Ingeniero White Harbor (S2: near thermoelectric plant, S3: fishing and recreational zone); S4: Galván Harbor (industrial harbor, gas, and oil loading buoy); S5: Cuatreros Harbor (fishing and recreational port); and S6: Villarino Viejo (rural zone). 
(a)

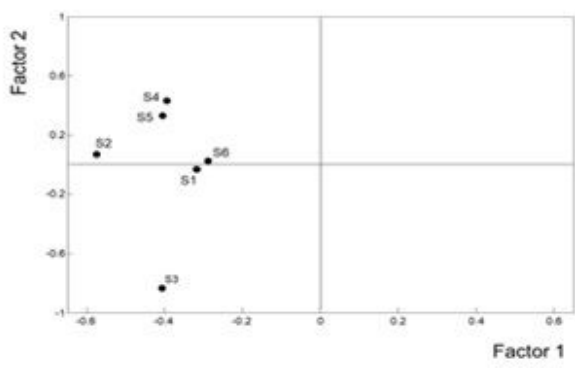

K-mode

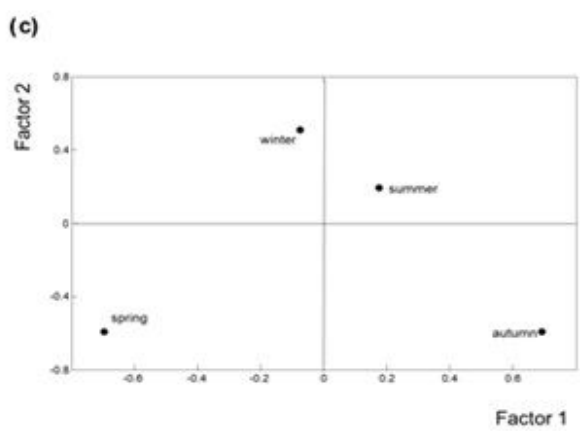

L-mode

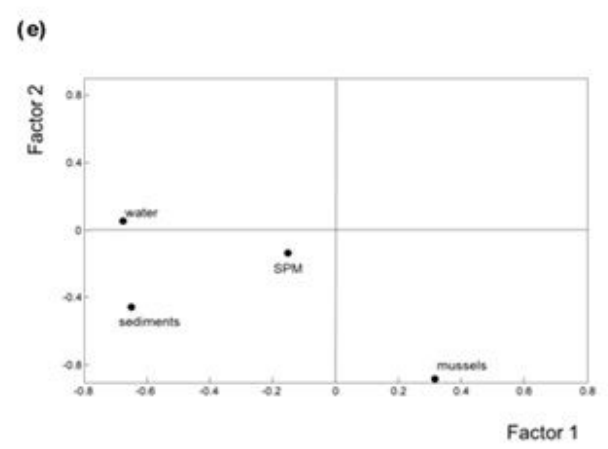

$J$-mode

(b)

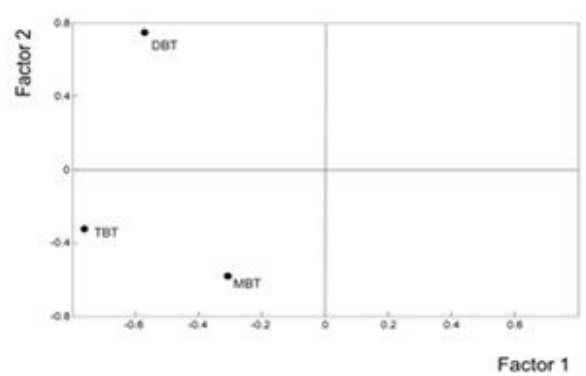

(d)

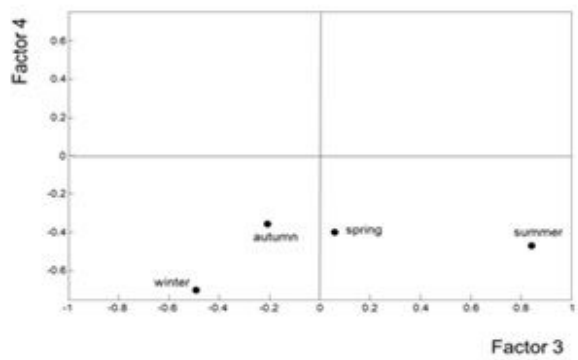

(f)

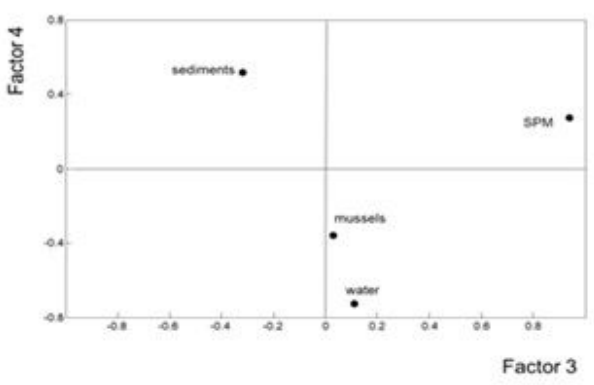

Figure 2

(a) Loading plots for the I-mode (sampling sites), (b) loading plots for the J-mode (BTs), (c)-(h) loading plots for the K-mode (season) and (i)-(n) loading plots for the L-mode (compartments) obtained by Tucker4 model.

\section{Supplementary Files}


This is a list of supplementary files associated with this preprint. Click to download.

- FigureS1.pdf

- Figures2.tif

- FigS3.tif

- SupplementaryTables.docx 